\title{
The Extent of Transmission of Novel Coronavirus in Wuhan, China, 2020
}

\author{
Hiroshi Nishiura ${ }^{1,2, *(\mathbb{D}}$, Sung-mok Jung ${ }^{1}{ }^{(\mathbb{D}}$, Natalie M. Linton ${ }^{1}\left(\mathbb{0}\right.$, Ryo Kinoshita ${ }^{1}{ }^{\circledR}$, \\ Yichi Yang ${ }^{1}$, Katsuma Hayashi ${ }^{1}$, Tetsuro Kobayashi ${ }^{1}$, Baoyin Yuan ${ }^{1}$ and \\ Andrei R. Akhmetzhanov ${ }^{1}$ (i) \\ 1 Graduate School of Medicine, Hokkaido University, Kita 15 Jo Nishi 7 Chome, Kita-ku, Sapporo-shi, \\ Hokkaido 060-8638, Japan; seductmd@med.hokudai.ac.jp (S.-m.J.); nlinton@gmail.com (N.M.L.); \\ kinoshitaryo@gmail.com (R.K.); lukeyang1993@eis.hokudai.ac.jp (Y.Y.); katsuma5miffy@gmail.com (K.H.); \\ tootsieroll2910@gmail.com (T.K.); baoyinyuan@gmail.com (B.Y.); akhmetzhanov@gmail.com (A.R.A.) \\ 2 CREST, Japan Science and Technology Agency, Honcho 4-1-8, Kawaguchi, Saitama 332-0012, Japan \\ * Correspondence: nishiurah@med.hokudai.ac.jp; Tel.: +81-11-706-5066
}

Received: 22 January 2020; Accepted: 23 January 2020; Published: 24 January 2020

\begin{abstract}
A cluster of pneumonia cases linked to a novel coronavirus (2019-nCoV) was reported by China in late December 2019. Reported case incidence has now reached the hundreds, but this is likely an underestimate. As of 24 January 2020, with reports of thirteen exportation events, we estimate the cumulative incidence in China at 5502 cases (95\% confidence interval: 3027, 9057). The most plausible number of infections is in the order of thousands, rather than hundreds, and there is a strong indication that untraced exposures other than the one in the epidemiologically linked seafood market in Wuhan have occurred.
\end{abstract}

Keywords: epidemiology; foreigner; travel; migration; importation; emerging infectious diseases

\section{Introduction}

Since the announcement of a cluster of pneumonia cases of unknown etiology in Wuhan, Hubei Province, China, was made on 31 December 2019, many rapid virological, clinical, and epidemiological research responses have taken place [1,2]. The causative agent of the pneumonia is suggested to be a novel coronavirus $(2019-\mathrm{nCoV})$ of the same lineage (but genetically distinct) from the coronavirus causing severe acute respiratory syndrome (SARS) [1]. Cases in the initial cluster reported a common exposure-a seafood market in Wuhan where wild animals were served at a restaurant-indicating that a point-source zoonotic (animal-to-human) route was likely the main mode of transmission for those cases [2].

Although early reports from Wuhan [3] stated that (i) there were only tens of cases in the cluster and (ii) no human-to-human transmission was directly observed, the scientific community was alert to the possibility that the novel coronavirus would spread to other geographic locations-including other countries - via direct human-to-human transmission. In early January, the outbreak began to escalate rapidly with hundreds of cases now confirmed along with the presence of a few household clusters [4-7].

As of 24 January 2020, the cumulative incidence in China is 830 cases, of which 549 cases were diagnosed in Hubei, 26 in Beijing, 20 in Shanghai, and 53 in Guangdong. Additionally, twenty-six deaths have been linked to the outbreak [6,8], and thirteen cases were exported to Japan, Singapore, South Korea, Taiwan, Thailand, Vietnam and the United States as of 22 January 2020. Considering that enhanced surveillance has been underway in these importing countries, case ascertainment has been perhaps better in exported case data. 
Using a spatial back-calculation method and analyzing exported cases, we estimate the cumulative incidence of 2019-nCoV cases in China in real time, allowing us to update and discuss the extent of transmission at the source.

\section{Exported Cases}

Table 1 shows the incidence of exported cases by date of hospitalization and report. Due to the initial difficulty of diagnosis in the absence of established primer for polymerase chain reaction testing, the time lag between hospitalization and reporting was longer for early cases compared with that of more recent cases. Among the seven locations reporting importation, the total volume of inbound passengers from China was $m=63.1$ million per year in 2017 [9], of which $100 q=2.1 \%$ were from Wuhan [10], a home of $n=19.0$ million people as the catchment population of Wuhan airport. Two other locations with confirmed cases, i.e., Macau and Hong Kong, were excluded from the analysis, because it is commutable by land transporation and the first case in Hong Kong was indeed not via airtravel. As we already know from elsewhere [11-13], given the observed cumulative count of $c$ exported cases, we have a balance equation of the cumulative risk of infection:

$$
\hat{p}=c \frac{365}{m q T}
$$

where $T$ is the sum of incubation and infectious periods, and here is assumed to be 3.2 and 9.3 days [14], respectively, assuming that these periods are similar to those of other coronaviruses, and thus, $T=12.5$ days. The estimated incidence in China is then given by $\hat{p} n$. With an ad-hoc assumption that the data are generated following the binomial sampling process among travelers from Wuhan, the cumulative incidence is then estimated using a maximum likelihood method.

Table 1. Exportation events and estimated incidence in China.

\begin{tabular}{|c|c|c|c|c|}
\hline Importing location & Date of Hospitalization & Date of Report & Cumulative Count & $\begin{array}{l}\text { Estimated Incidence } \\
\text { in China }(95 \% \mathrm{CI})\end{array}$ \\
\hline Thailand & 8 January & 14 January & 1 & $423(\mathrm{NC}, 1863)$ \\
\hline Japan & 10 January & 16 January & 2 & $846(141,2614)$ \\
\hline Thailand & 13 January & 17 January & 3 & $1270(316,3292)$ \\
\hline South Korea & 19 January & 20 January & 4 & $1693(526,3933)$ \\
\hline Taiwan & 19 January & 21 January & 5 & $2116(759,4548)$ \\
\hline United States & 19 January & 21 January & 6 & $2539(1009,5145)$ \\
\hline Thailand & 19 January & 22 January & 7 & $2962(1273,5729)$ \\
\hline Thailand & NA & 22 January & 8 & $3385(1547,6302)$ \\
\hline Singapore & 22 January & 23 January & 9 & $3809(1830,6866)$ \\
\hline Vietnam & 22 January & 23 January & 10 & $4231(2121,7423)$ \\
\hline Vietnam & 22 January & 23 January & 11 & $4655(2418,7973)$ \\
\hline Japan & 22 January & 24 January & 12 & $5078(2720,8517)$ \\
\hline South Korea & 22 January & 24 January & 13 & $5502(3027,9057)$ \\
\hline
\end{tabular}

CI, confidence interval (the $95 \%$ CI was derived from bootstrapping); NC, not calculable; NA, not available. The estimated incidence is updated as a function of the date of the report [15-25].

Table 1 also shows the estimated incidence in China. The first exportation event in Thailand suggests 423 cases with the upper confidence limit of 1863 cases. The estimated cumulative incidence has grown as additional cases have been reported. As of 24 January 2020, with reports of thirteen exportation events, the cumulative incidence in China is estimated at 5502 cases ( $95 \%$ confidence interval: 3027, 9057).

Our latest estimate is comparable to a preliminary report posted by a research group at Imperial College London (ICL) on their own homepage on 22 January 2020 [26] that estimated the incidence based on three importation events at 4000 cases (95\% CI: 1000, 9700). Possible reasons for the slight difference include (i) the number of travelers in the previous study was derived from airline passenger data [27] and (ii) the assumed length of $T$ was different. Two other estimates have also been published: 
a preliminary study by a Northeastern University group estimated 1250 cases $(95 \%$ CI: 350, 3000) as of 17 January 2020 [28] and a University of Hong Kong group estimated 1343 cases (95\% CI: 547, 3446) as of 17 January 2020 [29]. The former study from the United States assumes that the catchment area population is 10 million (we use 11.1 million).

\section{The Way Forward}

The number of reported 2019-nCoV infections continues to grow as surveillance and detection methods improve. Our estimate and others $[26,28,29]$ agree that the actual number of cases is likely in the order of thousands, rather than hundreds, and there is a strong indication that untraced exposures other than that of the originally linked seafood market in Wuhan have occurred. Such exposures are expected to include human-to-human transmission, but the levels of transmissibility have yet to be quantified. It is still plausible that a substantial number of human infections arose from animal-to-human exposures, such as was the case during the first outbreak of highly pathogenic influenza (H7N9) in China, 2013, and the human-to-human transmissibility has yet to be quantified in an explicit manner.

Despite initially restricting what information on the outbreak was shared publicly, the Chinese government has begun to respectfully provide updates on the situation on a daily basis. This encourages the real-time release of information by means of regularly updated situation reports, including epidemiological information with dates of exposure, illness onset, and hospitalization among cases.

For researchers to be able to contribute to control efforts by improving situation awareness via an explicit risk assessment, it is crucial that detailed epidemiological data are posted to a public domain in real-time. Such datasets should include not only a deidentified line list of cases but also updates on the infection status of traced contacts. Information on exposure period and illness onset can assist with the estimation of important natural history parameters such as the incubation period. It is critical for the public health community and the public at large to understand more about the process of case ascertainment, including the current case definition and reporting system mechanisms.

Author Contributions: H.N. conceived the study, and all authors participated in the study design. H.N., S.-m.J. N.M.L., R.K., and Y.Y. collected the data. H.N. and S.-m.J. analyzed the data and H.N. drafted the manuscript. All authors gave comments on the earlier versions of the manuscript. All authors edited the manuscript and approved the final version.

Funding: H.N. received funding from the Japan Agency for Medical Research and Development (AMED) [grant number: JP18fk0108050]; the Japan Society for the Promotion of Science (JSPS) KAKENHI [grant numbers, H.N.: 17H04701, 17H05808, 18H04895 and 19H01074; R.K.: 18J21587], the Inamori Foundation, and the Japan Science and Technology Agency (JST) CREST program [grant number: JPMJCR1413]. S.M.J. and N.M.L. received graduate study scholarship from the Ministry of Education, Culture, Sports, Science and Technology, Japan.

Conflicts of Interest: The authors declare no conflicts of interest.

\section{References}

1. Cui, J.; Li, F.; Shi, Z.L. Origin and evolution of pathogenic coronaviruses. Nat. Rev. Microbiol. 2019, 17, 181-192. [CrossRef] [PubMed]

2. Hui, D.S.; I Azhar, E.; Madani, T.A.; Ntoumi, F.; Kock, R.; Dar, O.; Ippolito, G.; McHugh, T.D.; Memish, Z.A.; Drosten, C.; et al. The continuing 2019-nCoV epidemic threat of novel coronaviruses to global health-The latest 2019 novel coronavirus outbreak in Wuhan, China. Int. J. Infect. Dis. 2020, 91, 264-266. [CrossRef] [PubMed]

3. Wuhan Municipal Health Commission. Wuhan Municipal Health Commission's Briefing on the Current Pneumonia Epidemic in the City. 2020. Available online: http://wjw.wuhan.gov.cn/ (accessed on 22 January 2020).

4. World Health Organization. Novel Coronavirus-Japan (ex-China). 2020. Available online: https: //www.who.int/csr/don/17-january-2020-novel-coronavirus-japan-ex-china/en/ (accessed on 22 January 2020). 
5. World Health Organization. Novel Coronavirus-Republic of Korea (ex-China). 2020. Available online: https://www.who.int/csr/don/21-january-2020-novel-coronavirus-republic-of-korea-ex-china/en/ (accessed on 22 January 2020).

6. World Health Organization. Novel Coronavirus (2019-nCoV) Situation Report-1. 2020. Available online: https://www.who.int/docs/default-source/coronaviruse/situation-reports/20200121-sitrep-1-2019ncov.pdf (accessed on 22 January 2020).

7. Centers for Disease Control and Prevention. 2019 Novel Coronavirus, Wuhan, China. 2020. Available online: https://www.cdc.gov/coronavirus/2019-ncov/index.html (accessed on 22 January 2020).

8. CNN-World. Wuhan Coronavirus Death Toll Rises to Nine with 453 Infected Says China, Sparking Fears of Wider Spread. 2020. Available online: https://edition.cnn.com/2020/01/22/asia/china-wuhan-coronavirusdeadly-intl-hnk/index.html (accessed on 22 January 2020).

9. World Tourism Organization. Available online: https://www.unwto.org (accessed on 22 January 2020).

10. CEIC, Global Economic Data. 2020. Available online: https://www.ceicdata.com/en/country/china (accessed on 22 January 2020).

11. Dorigatti, I.; Hamlet, A.; Aguas, R.; Cattarino, L.; Cori, A.; Donnelly, C.A.; Garske, T.; Imai, N.; Ferguson, N.M. International risk of yellow fever spread from the ongoing outbreak in Brazil, December 2016 to May 2017. Euro. Surveill. 2017, 22, 30572. [CrossRef] [PubMed]

12. Tsuzuki, S.; Lee, H.; Miura, F.; Chan, Y.H.; Jung, S.-m.; Akhmetzhanov, A.R.; Nishiura, H. Dynamics of the pneumonic plague epidemic in Madagascar, August to October 2017. Euro Surveill. 2017, 22. [CrossRef] [PubMed]

13. Shimizu, K.; Nishiura, H.; Imamura, A. Investigation of the proportion of diagnosed people living with HIV/AIDS among foreign residents in Japan. J. Clin. Med. 2019, 8, 804. [CrossRef] [PubMed]

14. Lessler, J.; Reich, N.G.; Brookmeyer, R.; Perl, T.M.; Nelson, K.E.; Cummings, D.A.T. Incubation periods of acute respiratory viral infections: A systematic review. Lancet Infect. Dis. 2009, 9, 291-300. [CrossRef]

15. Kanagawa Prefecture. Outbreak of Patients with Pneumonia Associated with Novel Coronavirus. 2020. Available online: https://www.pref.kanagawa.jp/docs/ga4/prs/r6321422.html (accessed on 22 January 2020).

16. World Health Organization. Novel Coronavirus-Thailand (ex-China). 2020. Available online: https://www. who.int/csr/don/14-january-2020-novel-coronavirus-thailand-ex-china/en/ (accessed on 22 January 2020).

17. Thailand Ministry of Public Health-Bureau of Information Office of the Permanent Secretary of MOPH. Ministry of Public Health Receives 2 Tourists from Wuhan for Pneumonia at Bamrasnaradura Institute. 2020. Available online: https://pr.moph.go.th/?url=pr/detail/2/04/137232/ (accessed on 22 January 2020).

18. Kaixian, T.V. First Confirmed Case of New Coronavirus Pneumonia in Taiwan. 2020. Available online: http://www.kaixian.tv/gd/2020/0121/246352.html (accessed on 22 January 2020).

19. Washington State Department of Health-News Release. Case of 2019 Novel Coronavirus Confirmed in Washington State Resident. 2020. Available online: https://www.doh.wa.gov/Newsroom/Articles/ID/1068/ Case-of-2019-novel-coronavirus-confirmed-in-Washington-state-resident (accessed on 22 January 2020).

20. Reuters-WORLD NEWS. Macau Confirms First Wuhan Virus Case, Tightens Screening in Casinos. 2020. Available online: https://www.reuters.com/article/us-china-health-macau/macau-confirms-first-wuhanvirus-case-tightens-screening-in-casinos-idUSKBN1ZL0AR (accessed on 22 January 2020).

21. Channel News Asia. Wuhan Virus: 2 More Cases Confirmed in Thailand. 2020. Available online: https://www. channelnewsasia.com/news/asia/wuhan-virus-china-two-more-cases-found-thailand-12301606 (accessed on 22 January 2020).

22. Ministry of Health, Singapore. Confirmed imported case of novel coronavirus infection in Singapore; Multi-ministry taskforce ramps up precautionary measures. 2020. Available online: https://www.moh.gov.sg/news-highlights/details/confirmed-imported-case-of-novel-coronavirusinfection-in-singapore-multi-ministry-taskforce-ramps-up-precautionary-measures (accessed on 24 January 2020).

23. Xinhua News. Vietnam confirms first 2 novel coronavirus cases. 2020. Available online: http://www. xinhuanet.com/english/2020-01/23/c_138729956.htm (accessed on 24 January 2020).

24. Nikkei News. Novel pneumonia, 2nd case confirmed. Tourist from Wuhan. 2020. Available online: https://www.nikkei.com/article/DGXMZO54781090U0A120C2CE0000/ (accessed on 24 January 2020).

25. Korea Times. South Korea reports 2nd confirmed case of Wuhan coronavirus. 2020. Available online: https://www.koreatimes.co.kr/www/nation/2020/01/371_282433.html (accessed on 24 January 2020). 
26. Imperial College London-MRC Centre for Global Infectious Disease Analysis. News/Wuhan Coronavirus. 2020. Available online: https://www.imperial.ac.uk/mrc-global-infectious-disease-analysis/news-wuhancoronavirus/ (accessed on 24 January 2020).

27. Bogoch, I.I.; Watts, A.; Thomas-Bachli, A.; Huber, C.; Kraemer, M.U.G.; Khan, K. Pneumonia of unknown etiology in Wuhan, China: Potential for international spread via commercial air travel. J. Travel Med. 2020. [CrossRef] [PubMed]

28. Northeastern University. Laboratory for the Modeling of Biological and Socio-Technical Systems. 2020. Available online: https://www.mobs-lab.org/2019ncov.html (accessed on 22 January 2020).

29. The University of Hong Kong-HKUMed WHO Collaborating Centre for Infectious Disease Epidemiology and Control. Nowcasting and Forecasting the Wuhan 2019-nCoV Outbreak. 2020. Available online: https://www. med.hku.hk/news/press/HKUMed-WHO-Collaborating-Centre-for-Infectious-Disease-Epidemiologyand-Control-releases\%20real-time-nowcast-on-the-likely-extent-of-the-Wuhan-coronavirus (accessed on 22 January 2020).

(C) 2020 by the authors. Licensee MDPI, Basel, Switzerland. This article is an open access article distributed under the terms and conditions of the Creative Commons Attribution (CC BY) license (http://creativecommons.org/licenses/by/4.0/). 